\section{Investigation of the relationship between playfulness, digital game addiction and aggression levels of secondary school students in terms of various variables}

\author{
Ortaokul öğrencilerinin \\ oyunsallık, dijital oyun \\ bağımlılı̆̆ı ve saldırganlık \\ düzeyleri arasındaki ilişkinin \\ çeşitli değişkenler açısından \\ incelenmesi
}

\author{
Zekihan Hazar ${ }^{1}$ \\ Kürşat Hazar ${ }^{2}$ \\ Belgin Gökyürek ${ }^{3}$ \\ Muhsin Hazar ${ }^{4}$ \\ Sinan Çelikbilek ${ }^{5}$
}

\begin{abstract}
Introduction and Aim: The most basic problems that the developing technology brings to the life of children are the increasingly decreased physical games, the rapid increase of the digital game addiction and the violent games are pushing the aggressive behavior of the individuals. This research is important for the solution of the problem. Purpose of the research; The relationship between playfulness, digital game addiction and aggressiveness of middle school students in terms of various variables.
\end{abstract}

Method: In this research, which adopts the relational screening model, similar sampling method is used as the objective sampling method. In this direction, the study group is composed of the students from the 2016-2017 education period, the Türdü 100. Year Middle School students affiliated to the Muğla
Özet

Giriş ve Amaç: Gelişen teknolojinin çocukların yaşamına getirdiği en temel olumsuzluklar arasında fiziksel aktivite içerikli oyunların giderek azalması, dijital oyun bağımlılığının hızlı bir biçimde artması ve bununla bağlantılı olarak özellikle şiddet içerikli oyunların bireyleri saldırganlık davranışına itmesi gibi önemli sorunlar olarak karşımıza çıkmaktadır. Bu araştırma, yaşanan problemin çözümüne 1 şı tutması açısından önem taşımaktadır. Araştırmanın amacı; ortaokul öğrencilerinin oyunsallık, dijital oyun bağımlılığ1 ve saldırganlık düzeyleri arasındaki ilişkinin çeşitli değişkenler açısından incelenmesidir.

Yöntem: İlişkisel tarama modelinin benimsendiği bu araştırmada, amaçsal örnekleme yöntemlerinden benzeşik örnekleme yöntemi kullanılmıştır. Bu kapsamda çalışmanın örneklemini, 2016-2017 eğitim öğretim

\footnotetext{
1 Yrd. Doç. Dr., Niğde Ömer Halisdemir Üniversitesi, Beden Eğitimi ve Spor Yüksekokulu, zekihanhazar84@gmail.com

2 Okutman. Muğla Sttkı Koçkan Üniversitesi Spor Bilimleri Fakültesi, kursathazar@hotmail.com

${ }^{3}$ Yrd. Doç., Dr. Gazi Üniversitesi, Spor Bilimleri Fakültesi, inanb@gazi.edu.tr

${ }^{4}$ Doç. Dr., Gazi Üniversitesi, Spor Bilimleri Fakültesi, muhsin@gazi.edu.tr

${ }^{5}$ Okutman. Muğla Sitkı Koçkan Üniversitesi, Spor Bilimleri Fakültesi, sinancelikbilek@mu.edu.tr
} 
Hazar, Z., Hazar, K., Gökyürek, B., Hazar, M., \& Çelikbilek, S. (2017). Ortaokul öğrencilerinin oyunsallık, dijital oyun bağımlılı̆̆ı ve saldırganlık düzeyleri arasındaki ilişkinin çeşitli değişkenler açısından incelenmesi. Journal of Human Sciences, 14(4), 4320-4332. doi:10.14687/jhs.v14i4.5035

Provincial Directorate of National Education and Maltepe Secondary School students affiliated to the Ankara Provincial Directorate of National Education. $55.6 \%$ of the participants were female $(\mathrm{n}=213)$ and $44.4 \%$ were male $(\mathrm{n}$ $=170) \cdot 49.6 \%(\mathrm{n}=190)$ of participants attending Türdü 100.Yıl Secondary School, $50.4 \%$ of students attending Maltepe Secondary School $(n=193)$. Of the participants, $42 \%$ were 12 years $(\mathrm{n}=161), 27.7 \%$ were 13 years $(\mathrm{n}=$ $106)$ and $30.3 \%$ were 14 years old $(n=116)$. In order to collect data in the study, Playfulness Scale, Digital Game Addiction Scale for Children, and Aggression Scale were used. The obtained data were subjected to various analyzes using the SPSS 24.0 packet program.

Findings: According to research findings, participants' total scores on the scales were statistically significantly different between school type, sex and age variables. At the same time, it was found that the participants had a statistically significant relationship between the total scores of these three scales.

Conclusion and Discussion: As a result; Playability, digital game dependency and aggressiveness of middle school students are related to each other. Therefore, it can be said that it is important to investigate the problems to be solved by considering these three situations to solve the present problem.

Keywords: Playfulness; digital game addiction; aggression; child; game.

(Extended English abstract is at the end of this document) döneminde öğrenim görmekte olan Muğla İl Milli Eğitim müdürlüğüne bağl1 Türdü 100. Yıl Ortaokulu öğrencileri ile Ankara İl Milli Eğitim Müdürlüğüne bağlı Maltepe Ortaokulu öğrencileri oluşturmaktadır. Katılımcıların \% 55,6's1 kadin (n=213), \% 44,4'ü erkektir ( $n=170)$. Türdü 100.Y1l Ortaokulunda öğrenim görmekte olan katılımcıların oranı \% 49,6 iken $(\mathrm{n}=190)$, Maltepe Ortaokulunda öğrenim görmekte olan katılimc1 oran1 \% 50,4'tür $(\mathrm{n}=193)$. Katıllımciların \% 42'si 12 yaş $(\mathrm{n}=161)$, $\%$ 27,7'si 13 yaş $(n=106), \% 30,3$ ' ü 14 yaş $(n=116)$ grubundadır. Araştırmada veri toplamak amaciyla Oyunsallık ölçeği, Çocuklar İçin Dijital Oyun Bağımlilığ ölçeği ve Saldırganlık ölçeği kullanılmıştır. Toplanan veriler SPSS 24.0 paket program kullanılarak çeşitli analizlere tabi tutulmuştur.

Bulgular: Araştırma bulgularına göre katılımcıların ölçeklerden almış oldukları toplam puanlarının okul türü, cinsiyet ve yaş değişkenleri arasında istatistiksel olarak anlamlı düzeyde farkllık gösterdiği bulunmuştur. Aynı zamanda katılımciların bu üç ölçekten almış oldukları toplam puanlar arasinda istatistiksel olarak anlamlı düzeyde ilişki olduğu görülmüştür. Sonuç ve Tartişma: Sonuç olarak; ortaokul öğrencilerinin oyunsallık, dijital oyun bağımlılığı ve saldırganlık düzeylerinin birbirleri ile ilişkili olduğu dolayısıyla bu problemin tespit ve çözümüne yönelik yapılacak olan araştırmaların bu üç durumu göz önünde bulundurarak ele alınmasinın mevcut problemin çözümünde önemli olduğu söylenebilir.

Anahtar Kelimeler: Oyunsallik; dijital oyun bağımlılı̆̆; saldırganlık; çocuk; oyun.

\section{Giriş}

Hazar'a göre oyun (2000), bireylerin gün içerisindeki zorunlu faaliyetleri için ayırdıkları zaman haricinde kalan bölümlerde eğlence, sağllk ve eğitim gibi çeşitli amaçlar doğrultusunda gönüllü olarak yapılan, kendine has kuralları ve sınırlandırılmış yer ve zamanı olan zeka, yetenek ve dikkat gibi becerilerin yanında şans faktörünün ön planda olduğu ve sonucunda maddi ç1kar hedeflenmeyen eğlenceli etkinliklerdir.

Zaman içerisinde oyunların yapısında birtakım değişiklikler olsa da temel özellikler bakımından çok fazla farklılık yoktur. Hazar'ın yapmış olduğu tanım genel itibariyle bütün oyunları kapsamaktadır. Ancak yeni sayılabilecek bir oyun türü olan dijital oyunlar bazı yönleri ile bu tanımlamanın dışında kalmakta ve fiziksel aktivite içerikli oyunlar gibi oyunlardan beklenen faydanın aksine birtakım olumsuz sonuçlar doğurabilmektedir. 
Hazar, Z., Hazar, K., Gökyürek, B., Hazar, M., \& Çelikbilek, S. (2017). Ortaokul öğrencilerinin oyunsallık, dijital oyun bağımlılı̆̆ı ve saldırganlık düzeyleri arasındaki ilişkinin çeşitli değişkenler açısından incelenmesi. Journal of Human Sciences, 14(4), 4320-4332. doi:10.14687/ihs.v14i4.5035

Oyunsallık kavramının açıklanmasında kelime kökünün incelenmesi önemlidir. Türkçedeki “-sal” eki, İngilizcede “-ful” ekine karşıllk gelmektedir. Bu eklerin eklendiği kelimeye "-ilişkili, -ait" anlamlarını yüklediği görülmektedir. İngilizcedeki “-ness” eki, Türkçedeki “-lık” ekine karş1llk gelmektedir. İngilizcedeki "Playfulness" kavramı oyunla ilgili her şeyi tanımlamaktadır. Dolayısıyla "oyunsallık" kavramı da aynı anlamı taşımaktadır ( Temir, 1999 ve Zülfikar, 1991' den akt. Hazar, 2015). Başka örnekler verilecek olursa "fiziksellik", "duygusalllk" gibi kelimeler bu kavramlarla ilgili olan her şeyi açıklama da kullanıldığı gibi "oyunsallık" kelimesi de oyunla ilgili her şeyi ifade etmede kullanılabilir. Bu araştırma kapsamında "oyunsallık" kavramı, fiziksel hareketlilik içeren oyunları tanımlamak için kullanılmıştır.

Tuzgöl'e göre (2000), saldırganlık dört farklı şekilde sınıflandırılabilir. Bunlar; fiziksel saldırganlık, sözel saldırganlık, düşmanlık ve araçsal saldırganlık olarak tanımlanmaktadır. Sözel saldırganlık daha çok bireyi sözlerle rencide etme ve incitme şeklinde gerçekleşirken, fiziksel saldırganlık; doğrudan temasın yer aldığı vurma şeklinde gerçekleşmekte, düşmanlık ise olumsuz duygular temelinde yaşanan nefret ve sevmemeyi ifade ederken, araçsal saldırganlık ise daha çok karşıdakine zarar verme düşüncesi olmasına rağmen asıl amaç kişinin kendisini olduğundan daha güçlü göstermeye çalışmasıdır.

Postman, eskiden sokaklarda görebildiğimiz çocuk oyunlarının artık ortadan kalktı̆̆ını hatta çocuk oyunları düşüncesinin bile zihinlerden silindiğini belirtmektedir (Kıran, 2011). Kaya (2013), yakın zamana kadar özellikle park ve bahçe gibi açık oyun alanlarında oynanan birçok oyunun, günümüzde maalesef oyun salonları başta olmak üzere ev, iş yeri gibi kapalı, sınırlı ve yapay alanlara sıkıştı̆̆ını ifade etmektedir.

Dijital oyunlar, günümüz dünyasında çocukların temel yaşam aktivitelerinden birisi olmuş ve eğlence ve serbest zaman anlayışının önemli bir parçası haline gelmiştir. Öyle ki çocuklar buldukları ilk firsatta yapılacak aktiviteler arasında dijital oyun oynamayı ilk sıraya koymaktadır. Çocuklar için serbest zaman faaliyetlerinin en ön sırasında yer alan dijital oyunlar, çocukların sportif, kültürel, sanatsal ve sosyal faaliyetlerini hatta temel ihtiyaçları olan beslenme, uyku ve tuvalet gibi ihtiyaçlarını geri plana itmelerindeki en önemli etkenlerden birisi olarak karşımıza çıkmaktadır. Yaşanan bu durumun sonuçları arasında çocuğun sosyal yaşamdan koparak yalnızlaşması, duygusal birtakım sorunlar yaşaması, bedensel gelişimin olumsuz etkilenmesi ve en önemlisi dijital oyun bağımlısı olması gibi olumsuz durumlar yaşanabilmektedir.

Şahin ve Tuğrul'a göre (2012)Yapılan araştırmaların temelde iki başlık altında ele alındığını söyleyebiliriz. Araştırmaların bir bölümü dijital oyunların bireyin fizyolojik, bilişsel, sosyal ve duyuşsal gelişim alanlarına olumlu etkilerini savunurken, bir diğer bölümü ise bu görüşün aksi yönünde etkilerden bahsetmektedir. Arslan vd. (2014), bu oyunları erken dönemlerde oynamaya başlayan çocukların temel gelişim alanları (bilişsel, duyuşsal, psiko-motor, sosyal) açısından olumsuz etkileneceğini, ayrıca çocukları gerçek oyun kültüründen kopararak gerçek yaşamdan uzak, hayal dünyasında yaşayan bireyler haline getireceğini ifade etmektedirler.

Lieberman vd. (2009) dijital oyunların; şiddet ve korkuya sevk etme, duygusuzlaşma ve saldırganlık davranışı sergileme, zamanın büyük bir bölümünü keşfedici oyunlar yerine dijital oyunlarla harcama, fiziksel ve sosyal aktivitelerden uzak kalma gibi olumsuz sonuçlar doğurabileceğini ifade etmektedirler. Gentile ve Anderson (2006), dijital oyunların çocuklar üzerine olabilecek zararlı etkilerinin araştırıldı̆̆ birçok bilimsel çalışmanın olduğunu ve özellikle şiddet içerikli dijital oyunların kısa ve uzun vadede saldırganlık düşüncesi, saldırganlık hissi, saldırgan davranışlar ve sosyal davranışlarda azalma gibi olumsuz psikolojik ve sosyal sonuçlara yol açabileceğini ifade etmektedirler.

Şiddet içerikli oyunların kişide saldırgan tavırlarının yanında kötü madde kullanımını (sigara kullanımı, alkol tüketimi vb.) da arttırmaktadır. Bilgisayar oyunları özellikle 11-14 yaş grubundaki oyuncuları yetişkinlere oranla, erkek oyuncuları bayan oyunculara kiyasla daha fazla etkilemektedir. Aşırı düzeyde oyun oynamanın etkileri üzerine yapılan araştırmalarda saldırgan davranışlar, kişilik bozulmaları, bireylerde makineleşme, duyguların azalması, anti sosyal davranışlar, kişiler arası 
Hazar, Z., Hazar, K., Gökyürek, B., Hazar, M., \& Çelikbilek, S. (2017). Ortaokul öğrencilerinin oyunsallık, dijital oyun bağımlılı̆̆ı ve saldırganlık düzeyleri arasındaki ilişkinin çeşitli değişkenler açısından incelenmesi. Journal of Human Sciences, 14(4), 4320-4332. doi:10.14687/ihs.v14i4.5035

ilişkilerde bozulmalar gibi psikolojik problemler gözlenmiştir. Uzun süre bilgisayar başında oyun oynamanın fiziksel sağlık üzerinde birçok olumsuz etkileri vardır. Uzun süre hareketsiz kalınması ve gergin olunması boyunda ağrı ve tutulmaya sebep olmaktadır. Uzun süre sabit bir noktaya bakan gözlerde yorgunluk hissi, yanma ve kaşıntı ortaya çıkar. Bilgisayar başındayken oluşan duruş bozuklukları bel ve sırt ağrılarına da neden olmaktadır (Akçayır, 2013, s. 268).

Griffiths ve Meredith'e göre (2009), yapılan bilimsel araştırmalar sonucunda, dijital oyun bağımlılığının bireyler üzerinde psikolojik etkileri olarak; bireyin oyun esnasında kendisini mutlu ve zinde hissetmesi, oyun aktivitesini bitirememesi, oyunu özleme ve oynama süresindeki artış, aile ve arkadaşları görmezden gelme, oyun oynayamama durumunda depresif ve yalnız hissetme, oyun oynama davranışı ile ilgili yakın çevresine yalan söyleme ve okul ve iş hayatında problemlere yol açma gibi sorunlar ortaya çıkarken fizyolojik olarak; karpal tünel sendromu, göz kuruluğu, baş ve sırt ağrısı, düzensiz beslenme, kişisel bakım ve temizliğin aksatılması ve uyku bozukluğu gibi sorunlar ortaya çıkmaktadır.

Her geçen gün şiddet olaylarının daha fazla yaşandığı ve bu sorunun doğmasına yol açan etkenlerin neler olduğunun araştırılması önemli bir problem durumudur. Gelişen teknoloji ile birlikte fiziksel aktivite içerikli oyunlar giderek azalmakta, dijital oyunlar çocukların zamanlarını harcadıkları önemli bir aktivite haline gelmekte ve özellikle şiddet içerikli dijital oyunlar çocukları birtakım saldırgan davranışlara itmektedir. Bu bağlamda oyunsallık, dijital oyun bağımlılı̆̆ ve saldırganlık arasındaki ilişkinin incelenerek bilimsel verilerin ortaya konulması bu sorunun çözümüne yol gösterecektir.

\section{Yöntem}

\subsection{Evren}

Araştırmanın amacına bağlı olarak, üzerinde araştırma yapılabilecek veya genelleme yapılacak tüm bireylerin (birimlerin) oluşturduğu gruba evren denir (Erkuş, 2013, s. 118). Bu kapsamda araştırmanın evrenini Ankara ve Muğla İl Milli Eğitim Müdürlüklerine bağlı merkez ortaokullarında öğrenim gören, 12-14 yaş grubu öğrenciler oluşturmaktadır.

\section{2. Örneklem}

$\mathrm{Bu}$ kapsamda araştırmanın örneklemini; Ankara İl Milli Eğitim Müdürlüğü Maltepe Ortaokulu ve Muğla İl Milli Eğitim Müdürlüğüne bağlı Türdü 100. Yıl Ortaokulu'nda 2016-2017 eğitim öğretim döneminde öğrenim gören 213 kadın, 170 erkek olmak üzere toplam 383 öğrenci oluşturmaktadır.

\section{3. Verileri Toplama Arac1}

Araştırmada, Hazar ve Hazar tarafından 2016 yllında geliştirilmiş olan "Çocuklar İçin Dijital Oyun Bağımlılı̆̆1 Ölçeği”, Hazar tarafindan 2014'te geliştirilen "10-14 yaş Çocukların Fiziksel Aktivite İçeren Oyunları Oynamaya Yönelik Tutumları (Oyunsallık Ölçeği)" ve 1992 yılında Arnold, H. Buss ve Mark Peryy tarafindan geliştirilen, Arnold H. Buss ve W.L. Warren tarafindan 2000 yıllnnda güncellenen "Aggression Questionnaire” adlı ölçeğin Can tarafindan 2002 yılında Türkçeye uyarlanmış biçimi olan 'Saldırganlık Ölçeği” kullanılmıştır. Ölçeklerin her üçü de beşli likert șeklindedir.

\section{4.Ölçme Araçları}

Cocuklar İ̧̧in Dïital Oyun Băğmllĭğ̊ Ölçeğgi: Hazar ve Hazar tarafindan 2016 yllında 10-14 yaş grubu öğrencilerin katılımıyla, çocukların dijital oyun bağımlılığı düzeylerini belirlemek amacıyla geliştirilmiştir. Geliştirilmiş olan ölçek dört alt faktörlü olup toplam 24 maddeden oluşmaktadır. Ölçekteki ifadelerin değerlendirilmesinde 5 puanlı Likert tipi ölçekten yararlanılmıştır $(1=$ Hiç Katılmıyorum,..., 5 = Tamamen Katıllyorum). Ölçek alt faktörleri ve bu araştırma için güvenirlik değerleri şöyledir; Dijital Oyun Oynamaya Yönelik Aşırı Odaklanma ve Çatışma (.82), Oyun Süresinde Tolerans Gelişimi ve Oyuna Yüklenen Değer (.76), Bireysel ve Sosyal Görevlerin/Ödevlerin Ertelenmesi (.79), Yoksunluğun Psikolojik-Fizyolojik Yansıması ve Oyuna Dalma (.86). Ölçek madde toplamı (91). 
Hazar, Z., Hazar, K., Gökyürek, B., Hazar, M., \& Çelikbilek, S. (2017). Ortaokul öğrencilerinin oyunsallık, dijital oyun bağımlılı̆̆ı ve saldırganlık düzeyleri arasındaki ilişkinin çeşitli değişkenler açısından incelenmesi. Journal of Human Sciences, 14(4), 4320-4332. doi:10.14687/ihs.v14i4.5035

Saldirganlık Ölçeği; 1992 y1lında Arnold, H. Buss ve Mark Peryy tarafindan geliştirilen, Arnold H. Buss ve W.L. Warren tarafindan 2000 yllinda güncellenen “ Aggression Questionnaire” adlı ölçeğin Sibel Can tarafindan Türkçeye uyarlanmış biçimi olan 34 maddelik Saldırganlık Ölçeği kullanılmıştır. Ölçek alt faktörleri ve bu araştırma için güvenirlik değerleri şöyledir; fiziksel saldırganlık (.75), sözel saldırganlık (.70), öfke (.77), düşmanlık (.80), dolaylı saldırganlık (.81), ölçek madde toplamı (74). Ölçek 5'li likert tipi olup yanıtlama seçenekleri " $5=$ karakterime tamamen uygun", "4=karakterime çok uygun", " $3=$ Karakterime biraz uygun”, " $2=$ Karakterime çok az uygun", " $1=$ karakterime hiç uygun değil”" şeklindedir.

Oyunsallık Ölçeği; Hazar (2015) tarafından geliştirilen "10-14 Yaş Çocukların Fiziksel Aktivite İçeren Oyunları Oynamaya Yönelik Tutumları" ölçeği beş alt faktörden oluşmaktadır. Ölçek alt faktörleri ve bu araştırma için güvenirlik değerleri şöyledir; Oyun Sevgisi (.80), Risk Alma (.78), Sosyal Uyum (.83), Oyun Oynamay1 Arzulama (.71), Oyun Oynamaktan Keyif Alma (.88), ölçek madde toplamı (.77). Ölçek toplam 27 maddeden oluşmaktadır. Ölçekteki ifadelerin değerlendirilmesinde 5 puanlı Likert tipi ölçekten yararlanılmıştır $(1=$ Kesinlikle Katılmıyorum,..., 5 = Kesinlikle Katıllyorum) şeklindedir.

\section{5. Verilerin Toplanması ve Analizi}

Verilerin toplanması sürecinde; araştırmaya gönüllü olarak katılmayı kabul eden 400 öğrenciye ölçme araçları uygulanmış, doldurulan ölçeklerden 17'si araştırmanın geçerlik ve güvenirliğine uygun olmadığı gerekçesiyle değerlendirmeye alınmamıştır. Elde edilen veriler SPSS 24. Paket programında değerlendirilerek tanımlayıcı istatistik, $t$-Testi, tek yönlü varyans analizi (ANOVA), Post-Hoc test istatistikleri (Tukey HSD), Pearson Correlation analizlerine tabi tutulmuştur.

\section{Bulgular}

Tablo 1. Katılımcılara ait tanımlayıcı istatistik sonuçları.

\begin{tabular}{lcc}
\hline Cinsiyet & $\mathbf{N}$ & $\mathbf{f}$ \\
Kadın & 213 & $\% 55,6$ \\
Erkek & 170 & $\% 44,4$ \\
\hline Okul & & \\
Türdü 100. Y1l Ortaokulu & 190 & $\% 49,6$ \\
Maltepe Ortaokulu & 193 & $\% 50,4$ \\
\hline Yaş & & $\% 42$ \\
12 & 161 & $\% 27,7$ \\
13 & 106 & $\% 30,3$ \\
14 & 116 & $\% 100$ \\
\hline Toplam & 383 & \\
\hline
\end{tabular}

Katılımcıların \% 55,6’s1 kadın ( $n=213), \%$ 44,4'ü erkektir ( $n=170)$. Türdü 100.Y1l Ortaokulunda öğrenim görmekte olan katılımcıların oran1 \% 49,6 iken ( $\mathrm{n}=190)$, Maltepe Ortaokulunda öğrenim görmekte olan katıllımc1 oran1 \% 50,4'tür ( $\mathrm{n}=193)$. Yaş değişkenine bakıldığında; katılımcıların \% 42'si 12 yaş ( $n=161), \%$ 27,7'si 13 yaş (n=106), \%30,3’ ü 14 yaş $(\mathrm{n}=116)$ grubundadir.

\section{Okul Değişkenine Göre t-testi Sonuçları}

Katılımcıların okul değişkenine göre Oyunsallık Ölçeği, Dijital Oyun Bağımlılığı Ölçeği ve Saldırganlık Ölçeğinden almış oldukları toplam puan sonuçlarına göre fark analizleri t-test ile incelenmiştir. 
Hazar, Z., Hazar, K., Gökyürek, B., Hazar, M., \& Çelikbilek, S. (2017). Ortaokul öğrencilerinin oyunsallık, dijital oyun bağımlılı̆̆ı ve saldırganlık düzeyleri arasındaki ilişkinin çeşitli değişkenler açısından incelenmesi. Journal of Human Sciences, 14(4), 4320-4332. doi:10.14687/jhs.v14i4.5035

Tablo 2. Okul değişkenine göre t-testi sonuçları

\begin{tabular}{|c|c|c|c|c|c|}
\hline Okul & $\mathbf{N}$ & $\mathrm{AO}$ & Ss & $\mathbf{t}$ & $\mathrm{p}$ \\
\hline \multicolumn{5}{|c|}{ Oyunsallık } & \\
\hline & & 97,21 & 16,24 & \multirow[b]{2}{*}{4,55} & \multirow{8}{*}{,00 } \\
\hline \multirow{3}{*}{ Türdü 100. Yıl Ortaokulu } & \multirow{3}{*}{190} & 90,32 & 13,23 & & \\
\hline & & & & & \\
\hline & & 55,52 & 22,92 & & \\
\hline \multirow[t]{4}{*}{ Maltepe Ortaokulu } & 193 & 46,12 & 17,57 & 4,50 & \\
\hline & & \multicolumn{2}{|c|}{ Saldırganlık } & & \\
\hline & & 94,60 & 25,86 & 4.13 & \\
\hline & & 84,08 & 23,84 & 4,13 & \\
\hline
\end{tabular}

Yapılan analizler sonucunda, okul değişkenine göre katılımcıların Oyunsallık, Dijital Oyun Bağımlılığı ve Saldırganlık ölçeklerinden almış oldukları toplam puanlar arasında istatistiksel olarak anlamlı farklılık vardır. Ortalamalar dikkate alındığında bu farkın Türdü 100. Yıl Ortaokulu lehine olduğu görülmektedir.

Tablo 3. Katıllımcıların Cinsiyet değişkenine göre t-testi sonuçları

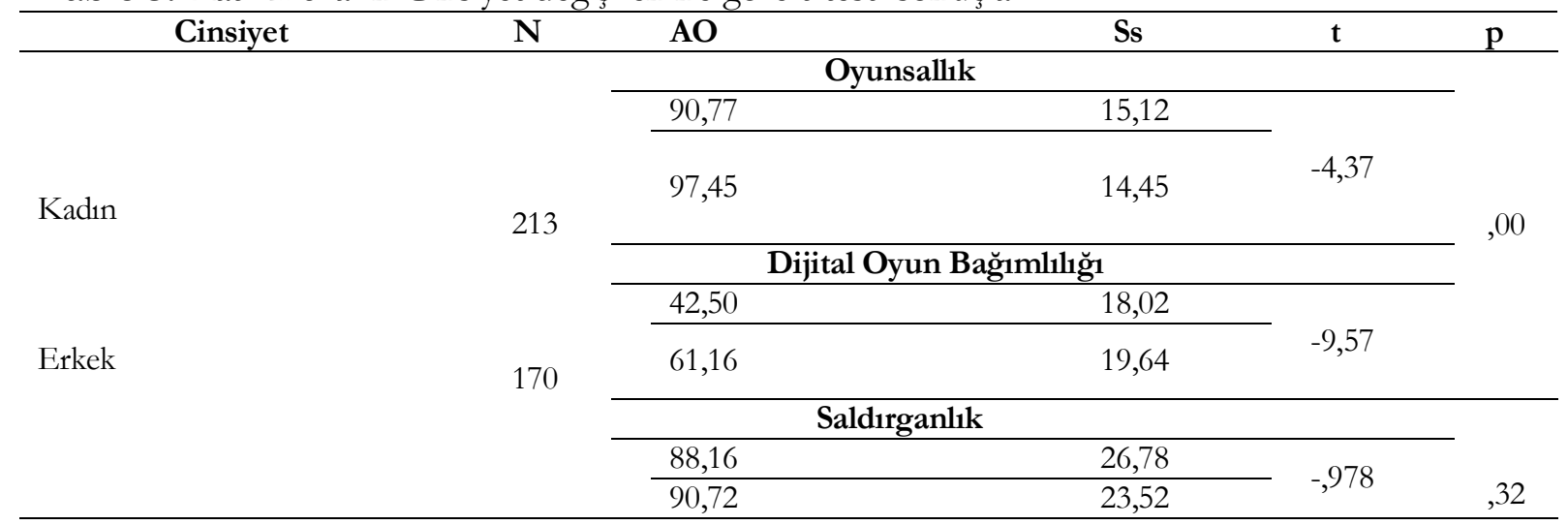

Yapılan analizler sonucunda, cinsiyet değişkenine göre katılımcıların Oyunsallık ve Dijital Oyun Bağımlılı̆̆ ölçeklerinden almış oldukları toplam puanlar arasında istatistiksel olarak anlamlı farklılık vardır. Ortalamalar dikkate alındığında bu farkın erkek katılımcılar lehine olduğu görülmektedir. Katılımcıların Saldırganlık ölçeğinden almış oldukları toplam puanların ise istatistiksel olarak anlamlı farklılık göstermediği sonucuna ulaşılmıştır.

Tablo 4. Oyunsallık Toplam Puanının Yaş Değişkenine Ait One-Way ANOVA Analiz Sonuçları

\begin{tabular}{|c|c|c|c|c|c|c|c|c|}
\hline Ölçüm & Yaş & $\begin{array}{c}\text { Varyansın } \\
\text { Kaynağ1 } \\
\end{array}$ & $\begin{array}{c}\text { Kareler } \\
\text { Toplamı } \\
\end{array}$ & $\begin{array}{c}\text { Serbestlik } \\
\text { Derecesi }\end{array}$ & $\begin{array}{c}\text { Kareler } \\
\text { Ortalamas1 }\end{array}$ & $\mathbf{F}$ & $p$ & $\begin{array}{c}\text { Anlamli } \\
\text { Fark }\end{array}$ \\
\hline \multirow[t]{2}{*}{ Oyunsallık } & $\begin{array}{l}12 \\
13\end{array}$ & $\begin{array}{l}\text { Gruplar } \\
\text { Arası }\end{array}$ & 6307,10 & 2 & 3153,55 & \multirow[t]{2}{*}{14,66} & \multirow[t]{2}{*}{,00 } & \multirow{2}{*}{$\begin{array}{l}12^{*}-14 \\
13^{*}-14\end{array}$} \\
\hline & 14 & Grup İçi & 81710,30 & 380 & 215,02 & & & \\
\hline
\end{tabular}

Yapılan analizler sonucunda; Yaşa göre Oyunsallık toplam puanının istatistiksel olarak anlamlı bir farklılık gösterdiği saptanmıştır $(\mathrm{F}=14,66) ; \mathrm{p}=0,00<0,01)$. Hangi gruplar arasında fark olduğunu ve bu farkın kaynağını tespit etmek için post-hoc test istatistikleri uygulanmıştır (Tukey HSD). Puan farkı lehine olan/oyunsallık düzeyi yüksek gruplar $\left(^{*}\right)$ ile gösterilmiştir. 12 yaş 
Hazar, Z., Hazar, K., Gökyürek, B., Hazar, M., \& Çelikbilek, S. (2017). Ortaokul öğrencilerinin oyunsallık, dijital oyun bağımlılı̆̆ı ve saldırganlık düzeyleri arasındaki ilişkinin çeşitli değişkenler açısından incelenmesi. Journal of Human Sciences, 14(4), 4320-4332. doi:10.14687/jhs.v14i4.5035

grubunun ortalaması $(97,42)$ ve 13 yaş grubunun ortalaması $(94,61), 14$ yaş grubunun ortalamasından yüksektir $(87,83)$ ve bu fark istatistiksel olarak anlamlıdır. 12 yaş grubunun ortalaması, 13 yaş grubunun ortalamasından yüksektir ancak bu fark anlamlı değildir.

Tablo 5. Dijital Oyun Bağımlılı̆̆ Toplam Puanının Yaş Değişkenine Ait One-Way ANOVA Analiz Sonuçları

\begin{tabular}{|c|c|c|c|c|c|c|c|c|}
\hline Ölçüm & Yaş & $\begin{array}{c}\text { Varyansın } \\
\text { Kaynağı } \\
\end{array}$ & $\begin{array}{c}\text { Kareler } \\
\text { Toplamı }\end{array}$ & $\begin{array}{c}\text { Serbestlik } \\
\text { Derecesi } \\
\end{array}$ & $\begin{array}{c}\text { Kareler } \\
\text { Ortalaması } \\
\end{array}$ & $\mathbf{F}$ & $\mathrm{p}$ & $\begin{array}{c}\text { Anlamli } \\
\text { Fark }\end{array}$ \\
\hline \multirow{3}{*}{$\begin{array}{l}\text { Dijital } \\
\text { Oyun } \\
\text { Bağımlılı̆̆1 }\end{array}$} & 12 & Gruplar & 2145,632 & 2 & 1072,816 & \multirow{3}{*}{2,47} & \multirow{3}{*}{0,08} & \multirow{3}{*}{-} \\
\hline & 13 & Aras1 & & & & & & \\
\hline & 14 & Grup İçi & 164916,237 & 380 & 433,990 & & & \\
\hline
\end{tabular}

Yapılan analizler sonucunda; Yaşa göre Dijital Oyun Bağımlılı̆̆ı toplam puanının istatistiksel olarak anlamlı bir farklılık göstermediği saptanmıştır $(\mathrm{F}=2,47) ; \mathrm{p}=0,08>0,05) .12$ yaş grubunun puan ortalaması (48,19), 13 yaş grubunun puan ortalaması (51,50), 14 yaş grubunun puan ortalaması $(53,73)$ olmasına rağmen gruplar arasındaki bu farkın istatistiksel olarak anlamlı olmadığ1 görülmüştür.

Tablo 6. Saldırganlık Toplam Puanının Yaş Değişkenine Ait One-Way ANOVA Analiz Sonuçları

\begin{tabular}{|c|c|c|c|c|c|c|c|c|}
\hline Ölçüm & Yaş & $\begin{array}{c}\text { Varyansın } \\
\text { Kaynağ1 }\end{array}$ & $\begin{array}{c}\text { Kareler } \\
\text { Toplamı }\end{array}$ & $\begin{array}{c}\text { Serbestlik } \\
\text { Derecesi } \\
\end{array}$ & $\begin{array}{c}\text { Kareler } \\
\text { Ortalamas1 }\end{array}$ & $\mathbf{F}$ & $\mathrm{p}$ & $\begin{array}{c}\text { Anlamli } \\
\text { Fark }\end{array}$ \\
\hline \multirow[t]{2}{*}{ Saldırganlık } & $\begin{array}{l}12 \\
13\end{array}$ & $\begin{array}{l}\text { Gruplar } \\
\text { Aras1 }\end{array}$ & 11373,167 & 2 & 5686,584 & \multirow[t]{2}{*}{9,19} & \multirow[t]{2}{*}{0,00} & \multirow{2}{*}{$\begin{array}{l}12-13^{*} \\
12-14^{*}\end{array}$} \\
\hline & 14 & Grup İçi & 234897,700 & 380 & 618,152 & & & \\
\hline
\end{tabular}

Yapılan analizler sonucunda; Yaşa göre Saldırganlık toplam puanının istatistiksel olarak anlamlı farklılık gösterdiği saptanmıştır $(F=9,19) ; p=0,00<0,01)$. Hangi gruplar arasında fark olduğunu ve bu farkın kaynağını tespit etmek için post-hoc test istatistikleri uygulanmıştır (Tukey HSD). Puan farkı lehine olan/saldırganlık düzeyi yüksek gruplar (*) ile gösterilmiştir. 13 yaş grubunun ortalaması $(94,61)$ ve 14 yaş grubunun ortalaması $(94,94), 12$ yaş grubunun ortalamasindan (82,98),14 yüksektir ve bu fark istatistiksel olarak anlamlıdır.

Tablo 7. Oyunsallık, Dijital Oyun Bağımlılı̆̆1 ve Saldırganlık Toplam Puanları Arasındaki Pearson Korelasyon Tablosu

\begin{tabular}{lccc}
\hline Değişkenler (Ölçek toplam puanları) & Oyunsallık & Dijital Oyun Bağımlılı̆̆1 & Saldırganlık \\
\hline Oyunsallık & 1 &, 089 &,- 070 \\
Dijital Oyun Bağımlılığı &, 089 & 1 &, $364^{* * *}$ \\
Saldırganlık &,- 070 &, $364^{* * *}$ & 1 \\
\hline
\end{tabular}

Yapılan korelasyon analizi sonucunda katılimciların Oyunsallık toplam puanı ile Dijital Oyun Bağımlılığı toplam puanı arasında pozitif yönde bir ilişki olduğu ancak Saldırganlık puanı ile negatif yönde bir ilişki olduğu görülmüştür. Bununla birlikte katılımcıların Dijital Oyun Bağımlılı̆̆1 puanı ile saldırganlık puanı arasında oldukça yüksek düzeyde anlamlı pozitif ilişki olduğu görülmektedir. 
Hazar, Z., Hazar, K., Gökyürek, B., Hazar, M., \& Çelikbilek, S. (2017). Ortaokul öğrencilerinin oyunsallık, dijital oyun bağımlılı̆̆ı ve saldırganlık düzeyleri arasındaki ilişkinin çeşitli değişkenler açısından incelenmesi. Journal of Human Sciences, 14(4), 4320-4332. doi:10.14687/ihs.v14i4.5035

Katılımcılara İlişkin Dijital Oyun Bağımlılı̆̆ı, Oyunsallık ve Saldırganlık Düzeyleri

Tablo 8. Katılımcıların Dijital Oyun Bağımlılı̆̆1 Düzeyleri

\begin{tabular}{lccc}
\hline & Dijital Oyun Bağımlı̆̆ı̆1 Düzeyi & \\
\hline & $\mathbf{f}$ & $\mathbf{0}$ & Birikimli \% \\
Kesinlikle bağımlı değil & 23 & 6 & 6,0 \\
Bağımlı değil & 176 & 46 & 52,0 \\
Risk grubu & 119 & 31 & 83,0 \\
Bağımlı & 52 & 13,6 & 96,6 \\
Yüksek düzeyde bağımlı & 13 & 3,4 & 100,0 \\
Toplam & 383 & 100,0 & \\
\hline
\end{tabular}

Analiz sonuçlarına göre katılımcıların \%52'si (n=199) dijital oyun bağımlilığı davranış1 göstermemektedir. Ancak risk grubu aralığı, bağımlı aralığı ve yüksek düzeyde bağımlı aralığında yer alan katılımc1 oranı \%48 ( $\mathrm{n}=184)$ olarak bulunmuştur.

Tablo 9. Katılımciların Oyunsallık Düzeyleri

\begin{tabular}{lccc}
\hline & Oyunsallık Düzeyi & Birikimli \% \\
\hline Çok zayıf & f & - & - \\
Zaylf & - & 1,0 & 1,0 \\
Orta & 4 & 24,5 & 25,6 \\
İyi & 94 & 62,7 & 88,3 \\
Çok iyi & 240 & 11,7 & 100 \\
Toplam & 45 & 100 & \\
\hline
\end{tabular}

Analiz sonuçlarına göre katılımcıların \%1’i $(n=4)$ zayıf düzeyde oyunsallık davranışına sahiptir. Ancak orta düzey, iyi düzey ve çok iyi düzeyde oyunsallık davranışına sahip olan katılımcı oran1 \%99 $(\mathrm{n}=379)$ olarak bulunmuştur.

Tablo 10. Katılımciların Saldırganlık Düzeyleri

\begin{tabular}{|c|c|c|c|}
\hline \multicolumn{4}{|c|}{ Saldırganlık Düzeyi } \\
\hline & $\mathrm{f}$ & $\%$ & Birikimli \% \\
\hline Düşük & 44 & 11,5 & 11,5 \\
\hline Normal & 266 & 69,5 & 80,9 \\
\hline Yüksek & 73 & 19,1 & 100,0 \\
\hline Toplam & 383 & 100 & \\
\hline
\end{tabular}

Analiz sonuçlarına göre katılımcıların \%11'i (n=44) düşük düzeyde, \%69,5’i (n=266) normal düzeyde saldırganlık davranışına sahiptir. Ancak yüksek düzeyde saldırganlık davranışına sahip olan katılımc1 oran1 \%19,1 $(\mathrm{n}=73)$ olarak bulunmuştur.

\section{Tartışma ve Sonuç}

Araştırma bulgularında, okul değişkenine göre katılımcıların Oyunsallık ölçeğinden almış oldukları toplam puanlar incelendiğinde, Türdü 100. Yıl Ortaokulu'nda öğrenim gören öğrencilerin puan ortalamasının (97,21), Maltepe Ortaokulu'nda öğrenim gören öğrencilerin ortalamasından $(90,32)$ yüksek olduğu görülmektedir $(t=4,55 ; \mathrm{p}=, 00<0,01)$. Saldırganlık ölçeğinden almış oldukları toplam puanlar incelendiğinde de Türdü 100. Yıl Ortaokulu'nda öğrenim gören öğrencilerin puan ortalamasinın $(94,60)$, Maltepe Ortaokulu'nda öğrenim gören öğrencilerin ortalamasından $(84,08)$ yüksek olduğu görülmektedir ( $\mathrm{t}=4,13 ; \mathrm{p}=, 00<0,01)$.

Dijital Oyun Bağımlılı̆̆ ölçeğinden almış oldukları toplam puanlar incelendiğinde ise Türdü 100. Yıl Ortaokulu'nda öğrenim gören öğrencilerin puan ortalamasının (55,52), Maltepe Ortaokulu'nda öğrenim gören öğrencilerin ortalamasından $(46,12)$ yüksek olduğu görülmektedir $(\mathrm{t}=$ $4,50 ; \mathrm{p}=, 00<0,01)$. Bu farklın önemli nedenleri arasında; Ankara ilinde bulunan Maltepe Ortaokulu 
Hazar, Z., Hazar, K., Gökyürek, B., Hazar, M., \& Çelikbilek, S. (2017). Ortaokul öğrencilerinin oyunsallık, dijital oyun bağımlılı̆̆ı ve saldırganlık düzeyleri arasındaki ilişkinin çeşitli değişkenler açısından incelenmesi. Journal of Human Sciences, 14(4), 4320-4332. doi:10.14687/jhs.v14i4.5035

öğrencilerinin büyük şehirde yaşamaları ve burada gerek devlet gerekse özel sektöre ait merkezlerde sportif, kültürel ve sanatsal faaliyetler gibi alternatif faaliyet imkanlarının, Muğla İlinde bulunan Türdü 100. Yıl Ortaokul öğrencilerine göre daha fazla olması öğrencilerin boş zamanlarını sadece dijital oyun oynamak yerine farklı etkinliklerle değerlendirmelerine imkan tanıması bu farkın temel nedeni olabilir. Benzer bir araştırma yapan Çakır (2013), çalışmasında; çocukların önemli bir bölümünün bilgisayar oyunlarını zaman geçirmek amacıyla oynadığı ve çocukların zamanlarını geçirebilecek başka aktivitelerden yoksun olduğu sonucuna varmıştır. Ergin vd. (2013), yaptığı bir araştırmalarında; herhangi bir sosyal kulübe gidenlerin riskli-bağımlı olma düzeyi gitmeyenlere göre anlamlı derecede düşük çıkmıştır. Düzenli spor yapanların riskli-bağımlı olma düzeyinin yapmayanlara göre anlamlı derecede yüksek olduğu tespit edilmiştir.

Araştırma bulgularında, cinsiyet değişkenine göre katılımcıların Oyunsallık ölçeğinden almış oldukları toplam puanlar incelendiğinde, erkek öğrencilerin puan ortalamasının (97,45), kadın öğrencilerin puan ortalamasından $(90,77)$ daha yüksek görülmektedir (t:-4,37/p: ,00<0,05). Bu farkın temel nedenleri arasında; erkek öğrencilerin kadın öğrencilere göre gerek okul sporları gerekse okul dissı merkezlerde alternatif spor ve oyun aktivitelerine daha fazla katılabilmeleri gösterilebilir. Koca (2006)'ya göre, özellikle ataerkil toplum anlayışında oluşturulan toplumsalcinsiyet rolleri gereği spor erkeğe özgü bir etkinlik olarak görülmekte ve bu konuda kadın ikinci planda yer almaktadır. Özellikle aileler erkek çocuklarını spora yönlendirirken çocuklarının erkekliklerini geliştirme ve kanıtlama düşüncesiyle hareket ederken, kız çocukları açısından ise sporu, bedenin ve cinsel kimliğinin zarar görmesine neden olabilecek bir etkinlik olarak değerlendirmektedirler. Bu nedenle Türkiye'de erkek çocukların spora katılım düzeyi kız çocuklardan daha fazla olmaktadır.

Katılımcıların cinsiyet değişkenine göre Dijital Oyun Bağımlılı̆̆ı ölçeğinden almış oldukları toplam puanlar incelendiğinde yine erkek öğrencilerin $(61,16)$ ortalamasının, kadın öğrencilerin ortalamasından $(42,50)$ daha yüksek olduğu görülmektedir (t:-9,57/ p: ,00<0,05). Günümüzde teknolojinin giderek ucuzlaması ve kolay ulaşılabilir olması gerek erkek gerekse kız çocukların bilgisayar, tablet, oyun konsolu, cep telefonu gibi bu oyun araçlarına kolay bir şekilde erişmesine imkan tanımaktadır. Ancak dijital oyun oynamak amaciyla internet cafeler veya oyun salonlarına giden bireylerin daha çok erkek ağırlıklı olması erkek çocukların bu oyunları kız çocuklara göre daha rahat ve daha fazla oynamalarına imkan tanımaktadır. Dolayısıyla araştırma sonucunda ortaya çıkan bu farkın temel nedeni olarak bu durum gerekçe gösterilebilir. Horzum'un (2011), yapmış olduğu benzer bir çalışmada, erkek öğrencilerin kız öğrencilere göre oyun bağımlılı̆̆ düzeyinin daha yüksek olduğunu bulunmuştur. Akçayır'a göre (2013), bilgisayar oyunları özellikle 11-14 yaş grubundaki oyuncuları yetişkinlere oranla, erkek oyuncuları bayan oyunculara kıyasla daha fazla etkilemektedir. Irles ve Gomis (2015) "Dürtüsellik ve video oyunu bağımlllı̆ı" konulu araştırmada; erkek katılımcıların bilgisayar başında geçirdikleri süre ve sıklık düzeyi ile video bağımlllı̆ı düzeyinin kadınlara göre anlamlı düzeyde daha yüksek olduğunu tespit etmişlerdir. Fröolich vd. (2016), "Ergenlerde bilgisayar oyunu bağımlıllğı-klinik çalışma örneği” konulu araştırmada; katılımcıların bağımlılık düzeylerinin yaş değişkenine göre anlamlı bir farklılık göstermediğini tespit etmişlerdir.

Katılımcıların cinsiyet değişkenine göre Saldırganlık ölçeğinden almış oldukları toplam puanların ise istatistiksel olarak anlamlı farkllık göstermediği tespit edilmiştir. Katılımcıların içinde bulunduğu gelişim döneminin özellikleri dikkate alındığında, bu dönemde çocukların bilişsel, duyuşsal ve devinişsel yönlerden her iki cinste de benzer özellikler gösterdiği bilinmektedir. Dolayısıyla katılımcıların saldırganlık düzeyleri arasında istatistiksel olarak anlamlı bir farklılığın olmaması bu dönemin özellikleri ile açıklanabilir. Ancak alan yazın incelendiğinde bu bulguların aksi yönünde bulgular elde eden araştırmaların olduğu görülmektedir. Arslan vd. (2010), bir araştırmasında, erkeklerin saldırganlık puan ortalamaların kızlardan daha yüksek olduğunu ve bu farkın istatistiksel olarak anlamlı olduğunu bulmuşlardır. Yine Özgür, Yörükoğlu ve Arabacı (2011)'nın yaptığı benzer bir araştırmada erkek öğrencilerin saldırganlık düzeylerinin kadın öğrencilerden yüksek olduğunu ve bu farkın istatistiksel olarak anlamlı olduğunu bulmuşlardır. 
Hazar, Z., Hazar, K., Gökyürek, B., Hazar, M., \& Çelikbilek, S. (2017). Ortaokul öğrencilerinin oyunsallık, dijital oyun bağımlılı̆̆ı ve saldırganlık düzeyleri arasındaki ilişkinin çeşitli değişkenler açısından incelenmesi. Journal of Human Sciences, 14(4), 4320-4332. doi:10.14687/ihs.v14i4.5035

Katılımcıların yaş değişkenine göre Oyunsallık ölçeğinden almış oldukları toplam puanlar incelendiğinde; Oyunsallık toplam puanının istatistiksel olarak anlamlı bir farklılık gösterdiği saptanmıştır $(\mathrm{F}=14,66) ; \mathrm{p}=0,00<0,01) .12$ yaş grubunun ortalaması $(97,42)$ ve 13 yaş grubunun ortalaması (94,61), 14 yaş grubunun ortalamasından daha yüksektir $(87,83)$ ve bu fark istatistiksel olarak anlamlıdır. 12 yaş grubunun ortalaması, 13 yaş grubunun ortalamasından yüksek olmasına rağmen bu farkın anlamlı değildir. Katılımcıların içinde bulunduğu yaş özellikleri dikkate alındığında, daha küçük yaş grubunda yer alan öğrencilerin (12-13 yaş) oyun çağı-dönemi içinde bulunduklarını ancak 14 yaş grubunda bulunan öğrencilerin bu oyun çağı-dönemi olarak tanımlanan dönemden çıkarak daha çok ergen dönemi davranış özellikleri göstermesi bu farkın önemli nedenleri arasında değerlendirilebilir. Aksoy ve Dere Çiftçiye göre (2014), oyun bebeklik döneminde başlar, çocukluk döneminde zirve yapar, ergenlik yıllarında ise azalır ve yetişkinlik döneminde devam eder.

Katılımcıların yaş değişkenine göre Dijital Oyun Bağımlılı̆̆ ölçeğinden almış oldukları toplam puanlar incelendiğinde; 12 yaş grubunun puan ortalaması $(48,19), 13$ yaş grubunun puan ortalaması (51,50), 14 yaş grubunun puan ortalaması $(53,73)$ olmasına rağmen gruplar arasındaki bu farkın istatistiksel olarak anlamlı olmadığ görülmüștür $(\mathrm{F}=2,47) ; \mathrm{p}=0,08>0,05)$. Dijital oyunlardaki çeşitlilik dikkate alındığında her yaş grubunun özelliklerine ve farklı seviyelere göre birçok oyunun tasarlanmış olduğu görülmektedir. Dolayısıyla farklı yaş kademelerinde bulunan bireylerin kendi ilgi ve seviyelerine göre birçok dijital oyun alternatifinin bulunması, bu araştırma sonucunda elde edilen bulguların istatistiksel olarak farkl1lik göstermemesinin nedeni olarak ifade edilebilir. Lieberman ve diğerlerine göre (2009), teknolojinin gelişmesiyle birlikte elektronik araçlar kolayca ulaşılabilen ve kolayca taşınabilen oyun araçlarına dönüşmüş ve bu sayede dijital oyunlar çocukların üç yaşından itibaren zamanlarının büyük bir kısmını giderek artan bir şekilde harcadıkları oyunlar halini almıştır. Donati, Chiesi, Ammannato ve Primi (2015), "Oyunlarda çeşitlilik ve bağımlllık: Erkek ergenlerde, video oyunu çeşitliliği ve bağımlılık ilişkisi” konulu araştırmada benzer sonuçlara ulaşmışlardır. Araştırma sonuçlarına göre katılımcıların video oyunu bağımlılı düzeyi ile oyun çeşitliliği ve oyun oynama süresi arasında yüksek düzeyde pozitif ilişki olduğu görülmüştür. Ancak yaş değişkeni ile diğer değişkenler arasında herhangi bir ilişki olmadığı görülmüştür.

Katılımcıların yaş değişkenine göre Saldırganlık ölçeğinden almış oldukları toplam puanlar incelendiğinde; istatistiksel olarak anlamlı farklılık olduğu saptanmıştır $(F=9,19) ; p=0,00<0,01) .13$ yaş grubunun ortalaması $(94,61)$ ve 14 yaş grubunun ortalaması $(94,94), 12$ yaş grubunun ortalamasından (82,98),14 daha yüksektir ve bu fark istatistiksel olarak anlamlıdır. Çocukluk döneminden ergenliğe geçiş sürecinde, bireylerde ben merkezci düşünce yapısının daha fazla hakim olmaya başlaması, yakın ve uzak çevresi ile birtakım çatışmalar yaşamasına neden olmaktadır. Dolayısıyla bu dönemde çocukların daha agresif ve çatışmacı bir tutum sergileme eğiliminde olmaları bu farkın temel nedenleri arasında gösterilebilir.

Özgür, Yörükoğlu ve Arabacı (2011)'nın yaptığı benzer bir araştırmalarında 9., 10., 11. sınıf öğrencilerinin saldırganlık düzeyleri incelendiğinde öğrencilerin sınıf düzeyi arttıkça (doğal olarak yaş düzeyi arttıkça) saldırganlık düzeylerinin de istatistiksel olarak anlamlı artış gösterdiği sonucuna ulaşmışlardır.

Araştırma verilerine uygulanan korelasyon analizi sonucunda; katılımcıların Oyunsallik toplam puanı ile Dijital Oyun Bağımlılı̆̆ toplam puanı arasında pozitif yönde düşük bir ilişki olduğu $(, 089)$ ancak bu ilişkinin istatistiksel olarak anlamlı olmadığı görülmüştür. Alantar'ın yaptığı benzer bir araştırmada (1999); dijital oyun oynayan bireylerin oynamayan bireylere göre serbest zaman etkinlikleri olan spor, sinema, kitap okuma gibi etkinliklere daha fazla zaman ayırdıkları görülmüştür.

Oyunsallık puanı ile Saldırganlık puanı arasında negatif yönde bir ilişki olduğu $(-0,70)$ ve bu ilişkinin istatistiksel olarak anlamlı olmadığı görülmüştür. Bununla birlikte katılımcıların Dijital Oyun Bağımlılı̆̆1 puanı ile Saldırganlık puanı arasında pozitif yönde oldukça yüksek düzeyde $\left(, 364^{* * *}\right)$ anlamlı ilişki olduğu görülmektedir. Bu araştırma sonucunda; dijital oyun bağımlilığı yüksek olan öğrencilerin aynı zamanda saldırganlık düzeylerinin de yüksek olduğu görülmektedir. Yapılan bilimsel araştırma sonuçlarına göre; özellikle şiddet içerikli dijital oyunların devamlı bir şekilde 
Hazar, Z., Hazar, K., Gökyürek, B., Hazar, M., \& Çelikbilek, S. (2017). Ortaokul öğrencilerinin oyunsallık, dijital oyun bağımlılı̆̆ı ve saldırganlık düzeyleri arasındaki ilişkinin çeşitli değişkenler açısından incelenmesi. Journal of Human Sciences, 14(4), 4320-4332. doi:10.14687/jhs.v14i4.5035

oynanması, uzun vadede şiddet davranışının birey tarafından bilinçaltında normalleştirilmesine ve bunun yansıması olarak da davranışlarında bu şiddet ögelerinin yer almasına neden olmaktadır. Gentile ve Anderson (2006), dijital oyunların çocuklar üzerine olabilecek zararlı etkilerinin araştırıldığı birçok bilimsel çalışmanın olduğunu ve özellikle şiddet içerikli dijital oyunların kısa ve uzun vadede saldırganlık düşüncesi, saldırganlık hissi ve saldırgan davranışlarda artış meydana getirdiği ve sosyal davranışlarda azalma gibi olumsuz psikolojik ve sosyal sonuçlara yol açabileceğini ifade etmektedirler. Akçayır (2013), aşırı düzeyde oyun oynamanın bireyde saldırgan davranışlar, kişilik bozulmaları, makineleşme, duyguların azalması, anti sosyal davranışlar, kişiler arası ilişkilerde bozulmalar gibi psikolojik problemlere yol açtı̆̆ını ifade etmektedir. Anderson (2001), "Şiddet içerikli video oyunlarının saldırganlık davranışı, saldırganlık anlayışı, fizyolojik uyarılma ve sosyal davranışlara etkisi konulu bir meta-analiz çalışmasında, şiddet içerikli video oyunlarının çocuk ve genç yetişkinlerde saldırganlık davranışını pozitif yönde etkilediği sonucuna varılmıştır.

Analiz sonuçlarına göre katılımcıların \%52'si $(\mathrm{n}=199)$ dijital oyun bağımlılığı davranışı göstermemektedir. Ancak risk grubu aralığı, bağımlı aralığı ve yüksek düzeyde bağımlı aralığında yer alan katılımcı oranı \%48 ( $\mathrm{n}=184)$ olarak bulunmuştur. Elde edilen bu sonuçlar; katılımcıların yarıya yakınının problemli oyun oynama ve bağımlı düzeyde oyun oynama davranışına sahip olduklarını göstermektedir. Analiz sonuçlarına göre katılımcıların \%1’i $(n=4)$ zayıf düzeyde oyunsallık davranışına sahiptir. Ancak orta düzey, iyi düzey ve çok iyi düzeyde oyunsallık davranışına sahip olan katılımcı oranı \%99 $(\mathrm{n}=379)$ olarak bulunmuştur.

Analiz sonuçlarına göre katılımcıların $\% 11^{\prime} \mathrm{i}(\mathrm{n}=44)$ düşük düzeyde, $\% 69,5{ }^{\prime} \mathrm{i}(\mathrm{n}=266)$ normal düzeyde saldırganlık davranışına sahiptir. Ancak yüksek düzeyde saldırganlık davranışına sahip olan katılımc1 oran1 \%19,1 $(n=73)$ olarak bulunmuştur.

Sonuç olarak; ortaokul öğrencilerinin oyunsallık, dijital oyun bağımlılığı ve saldırganlık düzeylerinin birbirleri ile ilişkili olduğu dolayısıyla bu problemin tespit ve çözümüne yönelik yapılacak olan araştırmaların bu üç durumu göz önünde bulundurarak ele alınmasının mevcut problemin çözümünde önemli olduğu söylenebilir.

\section{1. Araştırmanın Sinırlılıkları}

Araştırmada ele alınan çalışma gruplarının farklı eğitim bölgelerinde yer alan katılımcılardan oluşturulması ve daha fazla çeşitlendirilmesi araştırmanın bulguları açısından daha kapsamlı sonuçlar verebilir. Bununla birlikte, sonraki dönemlerde yapılacak benzer araştırmalarda nitel araştırma modelinin de kullanılarak mevcut durumun nedenlerinin daha derinlemesine araştırılması, sorunun daha detaylı ve güçlü bir şekilde ele alınmasına katkı sağlayabilir.

\section{Kaynaklar}

Akçayır, G. (2013). Dijital oyunların sağlığa etkisi. M.A. Ocak. Eğitsel Dijital Oyunlar. Ankara: Pegem Akademi.

Alantar, M. (1999). Video oyunlarının ergenlerin denetim odakları, öz-kavramları ve serbest zaman değerlendirme etkinlikleri üzerindeki etkileri. M.Ü. Atatürk Eğitim Fakültesi Eğitim Bilimleri Dergisi, 11(1), 1-10.

Anderson A. \& Bushman, B.,J. (2001). Effects of violent video games on aggressive behavior, aggressive cognition, aggressive affect, physiological arousal, and prosocial behavior, Iowa State University A Meta-Analytic Review of the Scientific Literature. 12(5), 22-36.

Arslan, E. Bütün, P., Doğan, M., Dağ, H., Serdarzade, C. \& Arıca, V. (2014). Çocukluk çağmnda bilgisayar ve internet kullanmm. Izmir Dr. Behçet Uz Cocuk. Hastanesi Dergisi, 4(3), 195-201.

Büyüköztürk, Ş., Kılıç Çakmak, E., Akgün, Ö.,E., Karadeniz, Ş. \& Demirel, F. (2016). Bilimsel araştırma yöntemleri. Ankara: Pegem Akademi.

Can, Sibel (2002). Aggression questionnarire adlı ölçeğin türk popülasyonunda geçerlik ve güvenirlik

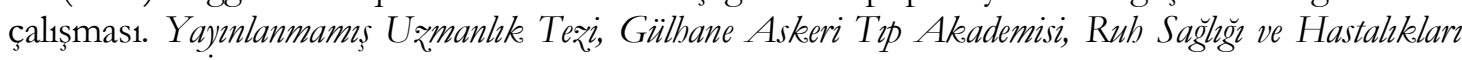
Servisi Şefliği, İstanbul. 
Hazar, Z., Hazar, K., Gökyürek, B., Hazar, M., \& Çelikbilek, S. (2017). Ortaokul öğrencilerinin oyunsallık, dijital oyun bağımlılı̆̆ı ve saldırganlık düzeyleri arasındaki ilişkinin çeşitli değişkenler açısından incelenmesi. Journal of Human Sciences, 14(4), 4320-4332. doi:10.14687/jhs.v14i4.5035

Çakır, H. (2013). Bilgisayar oyunlarına ilişkin ailelerin görüşleri ve öğrenci üzerindeki etkilerin belirlenmesi. Mersin Üniversitesi Ë̈itim Fakültesi Dergisi, 9(2), 138-150.

Çakır, Ö., Horzum, B.M., \& Ayas, T. (2013). İnternet bağımlılığının tanımı ve tarihçesi, internet bağımlılı̆̆1-sorunlar ve çözümler. Kalkan, M. \& Kaygusuz C. (Ed.), Ankara: Anı.

Donati, A.M., Chiesi, F., Ammannato, G. \& Primi, C. (2015). Versatility and addiction in gaming: the number of video-game genres played is associated with pathological gaming in male adolescents. Cyberpsychology, Behavior, and Social Networking, 18(2), 275-289.

Ergin, A., Uzun, S., U. \& Bozkurt, A.,İ. (2013). Tıp fakültesi öğrencilerinde internet bağımlılığ1 sıklığı ve etkileyen etmenler. Pam T⿰丨丨 Dergisi, 6(3), 134-142.

Erkuş, A. (2013). Davranış bilimleri için bilimsel araştırma süreci. Ankara: Seçkin.

Fröolich, J., Lehmkuhl, G., Orawa, H., Bromba, M., Wolf, K. \& Dorten, A. G. (2016). Computer game misuse and addiction of adolescents in a clinically referred study sample. Computers in Human Behavior, 55(16), 9-15.

Fröolich, J., Lehmkuhl, G., Orawa, H., Bromba, M., Wolf, K. \& Dorten, A. G. (2016). Computer game misuse and addiction of adolescents in a clinically referred study sample. Computers in Human Behavior, 55(16), 9-15

Gentile, D. A. \& Anderson, C. A. (2006). Video games. Encyclopedia of Human Development, 3(8), 1303 1307

Griffiths, M. D. \& Meredith, A. (2009). Videogame Addiction and its Treatment. Journal Contemp Psychother, 9(39), 247-253.

Hazar, M. (2015). A Study of Developing An Attitudes Scale of 18-22 Age Adults For Playing Games That Contain Physical Activity (Improving The 18-22 Age Playıng Games Scale). Niğde University Journal of Physical Education And Sport Sciences. Vol 9, Issue 1

Hazar, Z., Hazar, M. (2017). Çocuklar İçin Dijital Oyun Bağımllı̆̆ı Ölçeği. Journal of Human Sciences, 14(1), 203-216. doi:10.14687/jhs.v14i1.4387

Horzum, M. B. (2011). İlköğretim öğrencilerinin bilgisayar oyunu bağımlılık düzeylerinin çeşitli değişkenlere göre incelenmesi. Ë̆itim ve Bilim, 36(159), 57-68.

Irles, D.,L. \& Gomis, M.,L. (2015). Impulsiveness and Video Game Addiction-Impulsividad Adicción A Los Videojuegos. Health and Addictions. ISSN 1578-5319 ISSNe 1988-205X Vol. 16, No.1, 3340

Irles, D.,L., Gomis, M.,R. (2015). Impulsiveness and Video Game Addiction. Health and Addictions. ISSN 1578-5319 ISSNe 1988-205X. Vol. 16, No.1, 33-40

Kaya, B.A. (2013). Çevrimiçi oyun bağımllığı ölçeğinin geliştirilmesi. Yülksek Lisans Tę̧i, Gažiosmanpaşa Üniversitesi Eğitim Bilimleri Enstitïsü, Tokat.

Kıran, Ö. (2011). Şiddet içeren bilgisayar oyunlarının ortaöğretim gençliği üzerindeki etkileri. Yü̈ksek. Lisans Teri, Ondokurmayıs Üniversitesi Sosyal Bilimler Enstituisü, Samsun.

Lieberman, D.A., Fisk, M., C. \& Biely, E. (2009). Digital games for young children ages three to six: from research to design. Computers in the Schools, 26 (3), 299-313.

Şahin, C. \& Tuğrul, M. (2012). İlköğretim öğrencilerinin bilgisayar oyunu bağımlllık düzeylerinin incelenmesi. Zeitschrift für die Welt der Türken-Journal of World of Turks, 4(3), 15-30.

Tuzgöl, M (2000). Ana-Baba Tutumları Farklı Lise Öğrencilerinin Saldırganlık Düzeylerinin Çeşitli Değişkenler Açısından İncelenmesi. Türk Psikolojik Damışma ve Rebberlik Dergisi. Cilt II, Sayl: 14, 3945

Koca, C. (2006). Beden Eğitimi ve Spor Alanında Toplumsal Cinsiyet İlişkileri. Spor Bilimleri Dergisi Hacettepe J. of Sport Sciences. 17 (2), 81-99

Aksoy, A.,B, Çiftçi, H.,D. (2014). Erken Çocukluk Döneminde Oyun. Ankara: Pegem Akademi

Arslan, C., Hamarat, E., Arslan, E., Saygin, Y. (2010). An Investigation of Aggression and Interpersonal Problem Solving in Adolescents. Elementary Education Online, 9(1), 379-388

Özgür, G., Yörükoğlu, G., Baysan Arabacı, L. (2011). Lise Öğrencilerinin Şiddet Alg1lan, Șiddet Eğilim Düzeyleri ve Etkileyen Faktörler. Psikiyatri Hemsireliği Dergisi - Journal of Psycbiatric Nursing;2(2):5360 
Hazar, Z., Hazar, K., Gökyürek, B., Hazar, M., \& Çelikbilek, S. (2017). Ortaokul öğrencilerinin oyunsallık, dijital oyun bağımlılı̆̆ı ve saldırganlık düzeyleri arasındaki ilişkinin çeşitli değişkenler açısından incelenmesi. Journal of Human Sciences, 14(4), 4320-4332. doi:10.14687/ihs.v14i4.5035

\section{Extended English Abstract}

Introduction and Aim: The most basic problems that the developing technology brings to the life of children are the increasingly decreased physical games, the rapid increase of the digital game addiction and the violent games are pushing the aggressive behavior of the individuals. This research is important for the solution of the problem. Some studies have been done to improve the learning of computer games; psychomotor, physiological, cognitive, social and emotional effects; developing intelligence, motivating, and amusing; in many studies it may be possible to talk about its negative effect. Purpose of the research; The relationship between playfulness, digital game addiction and aggressiveness of middle school students in terms of various variables. Words such as "physicality" and "emotionalism" are used to explain everything related to these concepts, and "playability" can also be used to express everything about the game. In the context of this research, the term "playability" has been used to describe games involving physical activity. Aggression can be classified as verbal or physical aggression as well as hostile aggression and instrumental aggression. Verbal aggression occurs verbally in the form of humiliation and humiliation. Physical aggression involves a physical act of hitting, tattooing. Hostile aggression is an aggression that is caused by the attacker's dislike or hate of the target and that is the underlying cause of harm, and can be described as a more pure form of aggressive behavior. Despite intent to harm vehicular aggression, the main purpose may be selfprotection or self-interest.

Method: In this research, which adopts the relational screening model, similar sampling method is used as the objective sampling method. In this direction, the study group is composed of the students from the 2016-2017 education period, the Türdü 100. Year Middle School students affiliated to the Muğla Provincial Directorate of National Education and Maltepe Secondary School students affiliated to the Ankara Provincial Directorate of National Education. 55.6\% of the participants were female $(n=213)$ and $44.4 \%$ were male $(n=170) .49 .6 \%(n=190)$ of participants attending Türdü 100.Y1l Secondary School, 50.4\% of students attending Maltepe Secondary School $(n=193)$. Of the participants, $42 \%$ were 12 years $(n=161), 27.7 \%$ were 13 years $(n=106)$ and $30.3 \%$ were 14 years old $(n=116)$. In order to collect data in the study, Playfulness Scale, Digital Game Addiction Scale for Children, and Aggression Scale were used. The obtained data were subjected to various analyzes using the SPSS 24.0 packet program. Findings: According to research findings, participants' total scores on the scales were statistically significantly different between school type, sex and age variables. At the same time, it was found that the participants had a statistically significant relationship between the total scores of these three scales. According to the analysis results, $52 \%$ of the participants ( $n=199)$ did not show the behavior of digital game addiction. However, $48 \%(n=184)$ of participants in the risk group interval, dependent interval and high dependent interval were found. These results obtained; Participants show that close to half of them have problem-playing and addictive gaming behavior. According to the results of the analysis, $1 \%(n=4)$ of the participants have weak playfulness behaviors. However, $99 \%(\mathrm{n}=379)$ were found to have moderate, good level and playfulness behaviors at very good level.According to the results of the analysis, $11 \%(n=44)$ of participants had low levels of aggression behavior and $69.5 \%(\mathrm{n}=266)$ had normal aggression behaviors. However, the rate of participants with high levels of aggression was $19.1 \%(\mathrm{n}=73)$

Conclusion and Discussion: As a result; Playability, digital game dependency and aggressiveness of middle school students are related to each other. Therefore, it can be said that it is important to investigate the problems to be solved by considering these three situations to solve the present problem. As a result; playability, digital game addiction and aggressiveness of secondary school students are related to each other. Therefore, it can be said that it is important for the solution of the present problem that the researches to be done for the determination and solution of this problem are taken into consideration in consideration of these three situations. Establishment of study groups in the study participants from different educational areas and further diversification can give more comprehensive results in terms of the findings of the research. However, further investigation of the causes of the present situation using the qualitative research model in similar studies to be conducted in later periods may contribute to a more detailed and robust treatment of the problems and solution methods. 